\title{
A Study on Factors Influencing the Determination of Moisture Content of Fibrous Peat
}

\author{
Pui Tau Shien, Seneviratne, H.N. and Dygku Salma Awg Ismail
}

\begin{abstract}
Fibrous peat is an undrained peat that usually possesses very high moisture content. However, not all experimental procedures are applicable for determination of moisture content of fibrous peat. This research is aimed at examining the determination of insitu moisture content of fibrous peat using field measurements. The peat soil samples were collected at shallow depths from Asajaya at Kota Samarahan and Taman Kopodims at Matang, Kuching Sarawak by using peat auger. The laboratory tests such as determination of moisture content, fiber content, particle density and ash content were conducted on the collected samples in order to establish relationships between the parameters. Undisturbed peat samples from Matang were subjected to falling head permeability test to determine the saturated permeability. The saturated sample were then allowed to drain freely to simulate the moisture loss possible during sampling when samples were brought out of boreholes. The test results showed that moisture content varies according to the drying temperature and position of the soil sample (top, middle and bottom) during sampling. Comparing samples from both locations, peat soil from Kota Samarahan possessed higher moisture content. The saturated permeability of peat sample was in the range of $2.62-3.05 \mathrm{~cm} / \mathrm{s}$. The free draining trial showed that moisture loss during sampling significantly influence the moisture content measurement. The variation in value of moisture content for fibrous peat may occurs due to several factors such as existing ground water table, sampling method by boring, existing standard test procedure which is not suitable for peat soils requirement and also because of the physical properties which varied according to depth of soil.
\end{abstract}

Keywords: Moisture content, fibrous peat, permeability, field measurement

\section{INTRODUCTION}

$\mathrm{M}$ OISTURE or water content is one of the most distinctive properties of peat as most of the physical characteristics of the peat are related to the amount of moisture present. There are many methods available for determination of moisture content of soils. However, not all test equipment and experimental procedures used with these methods are applicable in the case of fibrous peat soil as they are normally designed considering inorganic soils. Fibrous peat, which is also known as fibrist, is an undrained peat that usually possesses very high moisture content due to its high organic content and void ratio. Most of the peat materials are in fully saturated state as the ground water table is at a shallow depth.

The most common laboratory test for determination of moisture content of soil is the oven-drying method complying with British Standard (BS 1377 - 2: 1990) or American Society for Testing and Materials (ASTM D 2216). ASTM method D2216 which determines the free water or pore water content as a percentage based on moist and oven dried soil weight differences may generate erroneous information for soils with a high organic material content [1]. The BS 1377 - 2: 1990 also states that a microwave oven should not be used as definitive method in determining the moisture content of soils containing organic matter such as peat. This is caused by the difficulty in ensuring temperature of soil does not exceeds 110 ${ }^{\circ} \mathrm{C}$. However, peat soil samples may experience particle burning even at temperatures well below $110^{\circ} \mathrm{C}$.

Another factor of importance is the method of sampling by boring which may affect the measurement of field moisture content. This is because once a sample is taken at the particular point, the soil has been disturbed and its properties may be altered. This introduces another variable, the heterogeneity of the soil into the moisture measurements; also there may be internal migration of water or moisture loss during sampling. The loss of moisture due to free draining during removal of the sample from the borehole also may be of importance. As a result of the above, factors that will significantly affect the determination of moisture content of fibrous peat must be identified. The use of present testing techniques for peat moisture is unsatisfactory, and therefore it is necessary to establish more reliable methods for obtaining the moisture content of fibrous peat in the field.

Dygku Salma Awg Ismail is a lecturer with the Department of Civil Engineering, Faculty of Engineering, Universiti Malaysia Sarawak, Kota Samarahan 94300 Kota Samarahan, Sarawak, Malaysia (phone: +60 8258 3268; fax: +60 82583410 ; e-mail: aidsalma@feng.unimas.my).

Nimal Seneviratne is a Professor with the Department of Civil Engineering, Faculty of Engineering, University of Peradeniya, Sri Lanka.

T.S.Pui, Undergraduate student, Department of Civil Engineering, UNIMAS, Kota Samarahan 94300 Malaysia (e-mail:allyxian87@ gmail.com) 


\section{LITERATURE REVIEW}

Malaysia has a total 2.7 million ha of peat land and among its thirteen states, Sarawak the largest state comprises the biggest reserve of peat land of 1.66 million ha or 13\% of the state ([2] and [3]). According to Malaysian Soil Classification system for organic soils, peats are defined as organic soils having an organic content more than $75 \%$. Fibrous peat is characterized by a fibrous structure which consists of easily recognizable plant remains and retains some strength [4]. It is able to hold considerably amount of water due to the hollow, spongy and coarse nature of the organic particles [5]. Von Post scale is a well established field method to indicate the stages of decomposition of peat. It recognizes 10 degrees of humification from $\mathrm{H} 1$ which indicates little decomposed fibrous and light-coloured peat to H10 at the end of the scale for well decomposed, colloidal, dark-coloured material.

Peat soil has very high moisture content compared to common mineral soil. Field moisture content varies according to the type of peat where it may as low as $500 \%$ in some amorphous granular peat and up to $3000 \%$ had been recorded for the coarse fibrous material [6]. The occurrence of water present in the peat soil can be classified into physically and chemically bound water, capillary and film water, and immobilized water [7]. First stage of drying involves the removal of free water and water from large pores. The forces of capillary contraction increase and weakly bound intracellular and immobilized water is squeezed out on further drying; this is followed by the removal of physic-chemically bound water ultimately.

\section{PRESENT STUDY}

The peat samples were collected from two locations which are Taman Kopodims at Matang (N 01³5.466’, E 110¹6.464’) and Asajaya at Kota Samarahan (N 01²5.751', E 110³2.476’), in state of Sarawak, Malaysia.

\section{Method of Sampling}

There are two types of samples collected from the both of the locations, namely, borehole samples and undisturbed samples. $50 \mathrm{~cm}$ high $\times 50 \mathrm{~mm}$ diameter borehole samples were obtained by using a hand auger specially suited for sampling peat, at 0.5 meter and 1.0 meter depth. The sample was divided into three parts: top, middle and bottom immediately after it is brought to ground surface. A trial pit was excavated to a depth just below the ground water table for undisturbed sampling purpose. Two cylindrical moulds were used: permeability mould $(95.58 \mathrm{~mm}$ diameter $\times 130 \mathrm{~mm}$ height $)$ and CBR mould (149.1 mm diameter $\times 132.72 \mathrm{~mm}$ height) were used to obtain undisturbed samples. These moulds were pushed into the trial pit to obtain the undisturbed peat samples.

\section{Field Investigation and Laboratory Tests}

The condition of the peat soil was investigated based on its degree of decomposition and classified according to the Von Post scale. Besides, depth of the existing ground water table was recorded on site. In order to identify the factors influencing the determination of fibrous peat, several tests had been conducted. Measurement of peat moisture content for both disturbed and undisturbed sample was carried out in two stages drying at $60^{\circ} \mathrm{C}$ and $100^{\circ} \mathrm{C}$. At each temperature the specimens were kept in the oven until a constant weight was recorded.

The present laboratory test available for determination of fiber content is the ASTM D1997 - 91 (2008) Standard Test Method for Laboratory Determination of the Fiber Content of Peat Sample by Dry Mass. This test method is used to quantify the fiber content present in the peat soil sample. The specific gravity test of the peat soil sample was measured using $50 \mathrm{ml}$ density bottle. Test specimen for specific gravity required to be ground to smaller size and sieving through the $425 \mu \mathrm{m}$ sieve. Meanwhile, determination of ash content is carried out in accordance to ASTM D-2974 Standard Test Methods for Moisture, Ash and Organic Matter of Peat and Other Organic Soils. Ash content of the peat is determined by igniting the oven-dried $\left(100{ }^{\circ} \mathrm{C}\right)$ sample in a muffle furnace at $550{ }^{\circ} \mathrm{C}$ according to Method $\mathrm{C}$ in ASTM standards.

The undisturbed peat soil sample was allowed to saturate by immersion in a water bath prior to laboratory testing. Two resaturation methods were used: falling head permeability apparatus and immersion in a water bath. The water was allowed to flow through the sample in permeability mould while the permeability was measured during partially and fully saturated stages. Another undisturbed sample was soaked in the water for a period of time for it to become saturated. Then, testing is carried out to determine the rate of moisture loss of the sample by allowing it to drain freely under gravity. This test method is used to simulate the loss of moisture during the field sampling of the peat soil. The initial saturated weight of the sample is 
recorded and the water in the sample is allowed to drip freely. The mass of the sample is recorded for every 5 minutes interval for the first half an hour followed by every 30 minutes interval thereafter.

\section{RESUlt AND ANALYSIS}

Table 1 shows the soil condition and water table based on the field investigation conducted at the two locations where the peat soil sample is collected.

Table 1: Field Investigation of Sampling Location.

\begin{tabular}{|c|c|c|c|c|}
\hline Location & \multicolumn{2}{|c|}{ Kota Samarahan } & \multicolumn{2}{c|}{ Matang } \\
\hline \multirow{3}{*}{$\begin{array}{c}\text { Soil condition (Von Post scale) } \\
\text { Degree of humification }\end{array}$} & \multicolumn{2}{|c|}{ Depth of sampling } & \multicolumn{2}{c|}{ Depth of sampling } \\
\cline { 2 - 5 } & $0.5 \mathrm{~m}$ & $1.0 \mathrm{~m}$ & $0.5 \mathrm{~m}$ & $1.0 \mathrm{~m}$ \\
\cline { 2 - 5 } & $\mathrm{H}_{4}$ & $\mathrm{H}_{2}$ & $\mathrm{H}_{4}$ & $\mathrm{H}_{3}$ \\
\hline Water table from ground level & \multicolumn{2}{|c|}{$0.38 \mathrm{~m}$} & \multicolumn{2}{c|}{$0.70 \mathrm{~m}$} \\
\hline
\end{tabular}

Measurement of Moisture Content

Moisture content was determined for both borehole and undisturbed peat soil samples. For the disturbed sample, determination of moisture content is carried out immediately at laboratory after field sampling. Moisture content is calculated according to (1).

Moisture content, $w=\left[\left(m_{\mathbf{2}}-m_{\mathbf{3}}\right) /\left(m_{\mathbf{3}}-m_{\mathbf{1}}\right)\right] \times 100 \%$

Where; $\mathrm{m}_{1}=$ Weight of the empty container

$\mathrm{m}_{2}=$ Weight of container + saturated peat soil sample

$\mathrm{m}_{3}=$ Weight of container + dried peat soil sample

\section{Disturbed Sample}

Two samples are obtained at a borehole and labeled as B1S1 and B1S2. B1 indicates the first borehole while S1 and S2 are samples at $0.5 \mathrm{~m}$ and $1.0 \mathrm{~m}$ depth respectively from ground surface. Each sample is then divided into three parts: top, middle and bottom as shown in Figure 1. For the test specimen of moisture content, each part of the soil sample is subdivided into three containers.

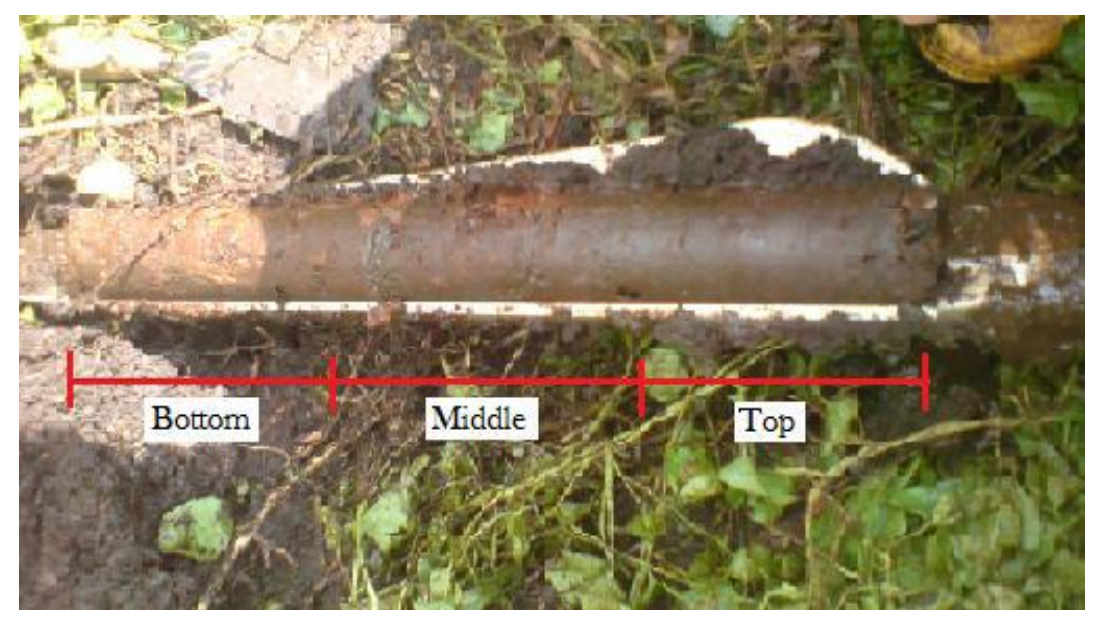

Figure 1: Peat soil sample divided into three parts;top, middle and bottom.

The peat soil sample undergoes two stages drying in this moisture content test; it is first oven-dried at $60^{\circ} \mathrm{C}$ until the mass of dry soil become stable and then transferred to oven with temperature of $100^{\circ} \mathrm{C}$. The bar charts in Figure 2 and Figure 3 
show that the moisture content values of peat soil increases with the increase of drying temperature from $60^{\circ} \mathrm{C}$ to $100^{\circ} \mathrm{C}$. This result conforms with the similar studies done previously. Samples from Kota Samarahan have the average increase in moisture content of $37.4 \%$ compared to that for sample from Matang which has a value of only 11.9\%. Moreover, the overall moisture content for peat soil in Kota Samarahan area is higher than that in Matang area.

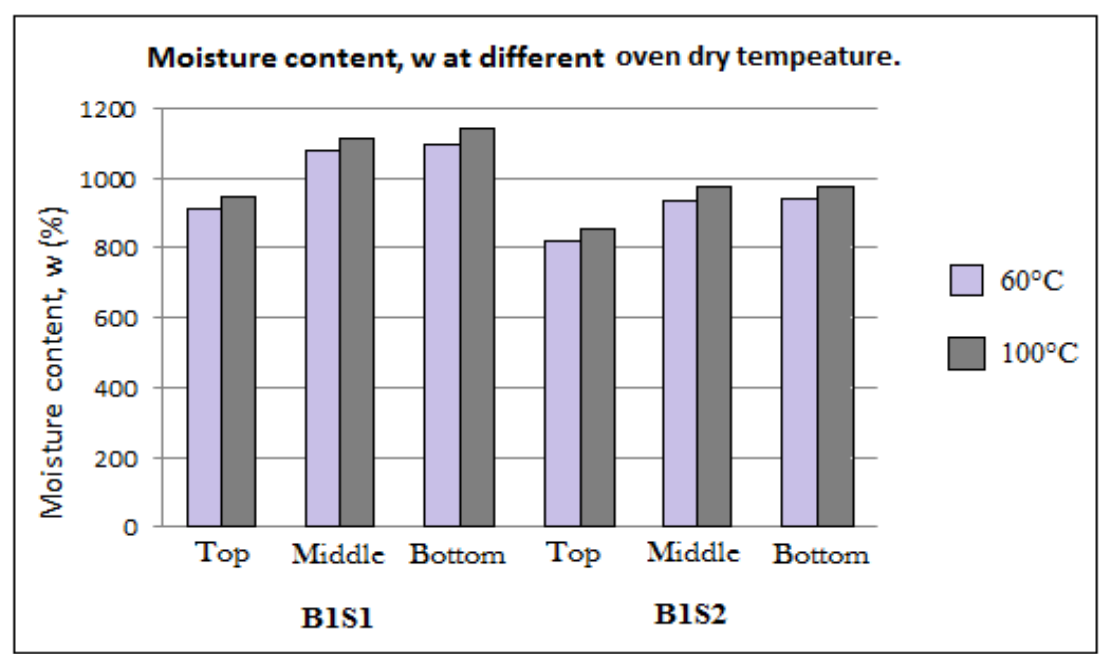

Figure 2: Graph of moisture content for Kota Samarahan area at different temperature.

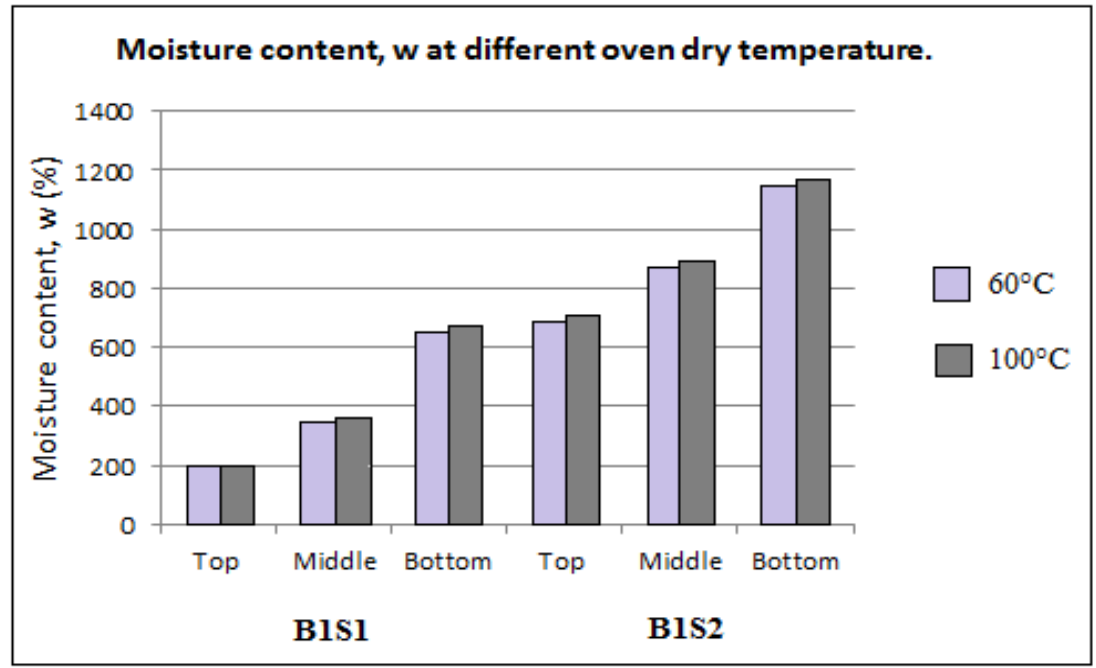

Figure 3: Graph of moisture content for Matang area at different temperature.

The moisture content of peat soil varies with depth in relation to ground water table. As shown in the bar charts, the soil below ground water table has a higher moisture content value. The sample B1S1 (0.5 m depth) from Kota Samarahan has higher moisture content as compared to sample B1S2 (1.0 m depth) as the first sample is taken just below the ground water table $(0.38 \mathrm{~m}$ depth). Meanwhile for sample from Matang area, the moisture content for the top part of sample B1S1 is the lowest as compared to other five parts of the peat soil sample in same borehole. This is because the ground water table is located at $0.70 \mathrm{~m}$ depth. Therefore, the moisture content of peat soil sample below $0.70 \mathrm{~m}$ is gradually increasing.

The result shows that bottom part for each sample possesses the highest moisture content when compared with top and middle part. This situation occurs as the water in the peat soil sample will flow migrate downwards to the bottom part of sampler when it is taken out from the borehole.

\section{Undisturbed Sample}

The determination of moisture content for the undisturbed sample is carried out after re-saturation. A portion of sample was taken for measurement of moisture content. The sample oven dried at $100{ }^{\circ} \mathrm{C}$ gave moisture content for peat soil in Kota Samarahan area (902.6\%) and that at Matang area (374.2\%). 


\section{Fiber Content}

The fiber content of peat soil was determined for both borehole and undisturbed sample by using equation (2). Each borehole sample is divided into top and bottom part. The sample is taken from the same location as moisture content samples but at a different borehole nearby, thus it is labeled as B2S1 (0.5 m depth) and B2S2 (1.0 m depth).

Fiber content $=\left[\left(\mathrm{M}_{2}-\mathrm{M}_{1}\right) / \mathrm{M}_{0}\right] \times 100 \%$

Where; $\mathrm{M}_{1}=$ Mass of empty $150 \mu \mathrm{m}$ sieve

$\mathrm{M}_{2}=$ Mass of $150 \mu \mathrm{m}$ sieve + dry retained fiber

$\mathrm{M}_{0}=$ Mass of original soil sample

Result has indicates that there are more fiber in the deeper soil at both locations. Fiber content obtained from Kota Samarahan and Matang at $1.0 \mathrm{~m}$ depth are $85.7 \%$ and $88.3 \%$ respectively. For the classification based on fiber content [8], the fibrous peat should consist of more than $66 \%$ fiber content to have a Von Post class of H4 or less. Based on Von Post scale all sample tested can be classified as fibrous peat. However, only sample at $1.0 \mathrm{~m}$ depth can be classified as fibrous peat according to the fiber content in the soil as the sample at $0.5 \mathrm{~m}$ depth consists of less than $66 \%$ fiber content (56.4\% for Matang area and $41.6 \%$ for Kota Samarahan).

\section{Specific Gravity}

Specific gravity (particle density) test is performed for both borehole and undisturbed peat soil samples. Equation (3) is used to compute the particle density. Two test specimens are prepared from the top, middle and bottom parts of borehole sample. The value of particle density for sample from Kota Samarahan ranges between 1.42 to $1.64 \mathrm{Mg} / \mathrm{m}^{3}$ while that from Matang ranges from 1.32 to $1.66 \mathrm{Mg} / \mathrm{m}^{3}$. Thus, comparing the particle density in both locations, it suggests that the particle density for peat soil in these locations is similar to each other.

Based on the data obtained from the laboratory test, the decrease in particle density will leads to the increase in moisture content. For example, the moisture content will keep on increasing as the particle density decrease from the top to bottom part of the sample at Matang.

Particle density,

$$
\rho_{\mathrm{s}}=\left(m_{\mathbf{2}}-m_{\mathbf{1}}\right) /\left[\left(m_{\mathbf{4}}-m_{\mathbf{1}}\right)-\left(m_{\mathbf{3}}-m_{\mathbf{2}}\right)\right]
$$

Where; $\mathrm{m}_{1}$ is the mass of density bottle (in $\mathrm{g}$ );

$\mathrm{m}_{2}$ is the mass of bottle and dry soil (in $\mathrm{g}$ );

$\mathrm{m}_{3}$ is the mass of bottle, soil and water (in $\mathrm{g}$ );

$\mathrm{m}_{4}$ is the mass of bottle when full of water only (in $\mathrm{g}$ ).

\section{Loss of Ignition/ Organic Matter Content}

Loss of ignition test is only conducted for the undisturbed sample at Kota Samarahan and Matang. Peat soil sample is dried at $100{ }^{\circ} \mathrm{C}$ before placing in the muffle furnace with temperature at $550{ }^{\circ} \mathrm{C}$ for a 4 hours duration.

The results on the undisturbed sample verified that the lower value of particle density indicates low mineral content whereby the lower value of particle density $\left(1.5 \mathrm{Mg} / \mathrm{m}^{3}\right.$ ) for peat soil at Kota Samarahan gives the lower ash content (mineral content) of $30.0 \%$. These values were within the range stated by researcher [9] which is from $20 \%$ to $80 \%$. Undisturbed sample from Matang on the other hand has particle density of $1.65 \mathrm{Mg} / \mathrm{m}^{3}$ with ash content of $37.4 \%$. Moreover, the lower ash content or higher organic matter content of sample is also related to the higher moisture content. The moisture content for undisturbed sample from Kota Samarahan is much higher as compared to sample from Matang.

Ash content, $\mathrm{N}(\%)=\left[\left(\mathrm{m}_{2}-\mathrm{m}_{\mathrm{c}}\right) /\left(\mathrm{m}_{1}-\mathrm{m}_{\mathrm{c}}\right)\right] \times 100$

Organic matter content $(\%)=100-\mathrm{N}$

Where; $\mathrm{m}_{\mathrm{c}}=$ Mass of empty crucible

$\mathrm{m}_{1}=$ Mass of crucible + oven dried sample

$\mathrm{m}_{2}=$ Mass of crucible + remaining sample after ignition 
Falling Head Permeability Test

This test is carried out in order to saturate the undisturbed peat soil sample collected from Matang area. The sample is placed in the permeability mould with internal diameter of $95.58 \mathrm{~mm}$ and length of $130 \mathrm{~mm}$. During the process of saturation, unsaturated and saturated permeability of the sample can be determined. The sample is assumed to be saturated when the permeability, $\mathrm{K}$ becomes constant. The data collected is used to plot the graph for $\log (\mathrm{h} 1 / \mathrm{h} 2)$ against time, $t$. From the gradient of each run of test, the permeability can be computed. The sample is saturated for three consecutive days. Figure 4, Figure 5 and Figure 6 show the experimental data while Figure 7 and Figure 8 depict the variation of partially saturated and fully saturated permeability with time. The permeability values become constant at the end of the test.

The value of permeability, $\mathrm{K}$ is decreasing as the soil sample becomes fully saturated. The coefficient of fully saturated permeability for the peat soil ranges from $10^{-07}$ to $10^{-06} \mathrm{~cm} / \mathrm{s}$. The previous study [10] indicated that the fibrous peat soil is averagely porous and has a medium range of permeability from $10^{-6}$ to $10^{-3} \mathrm{~cm} / \mathrm{s}$. The hydraulic conductivity for undisturbed peat soils from present tests is in a range of $4 \times 10^{-2}$ to $9 \times 10^{-8} \mathrm{~cm} / \mathrm{s}$. The permeability of peat depends on the void ratio, mineral content, degree of decomposition, chemistry and the presence of gas in soil. In general, a clear tendency of decreasing value with increasing decomposition had been established [11].

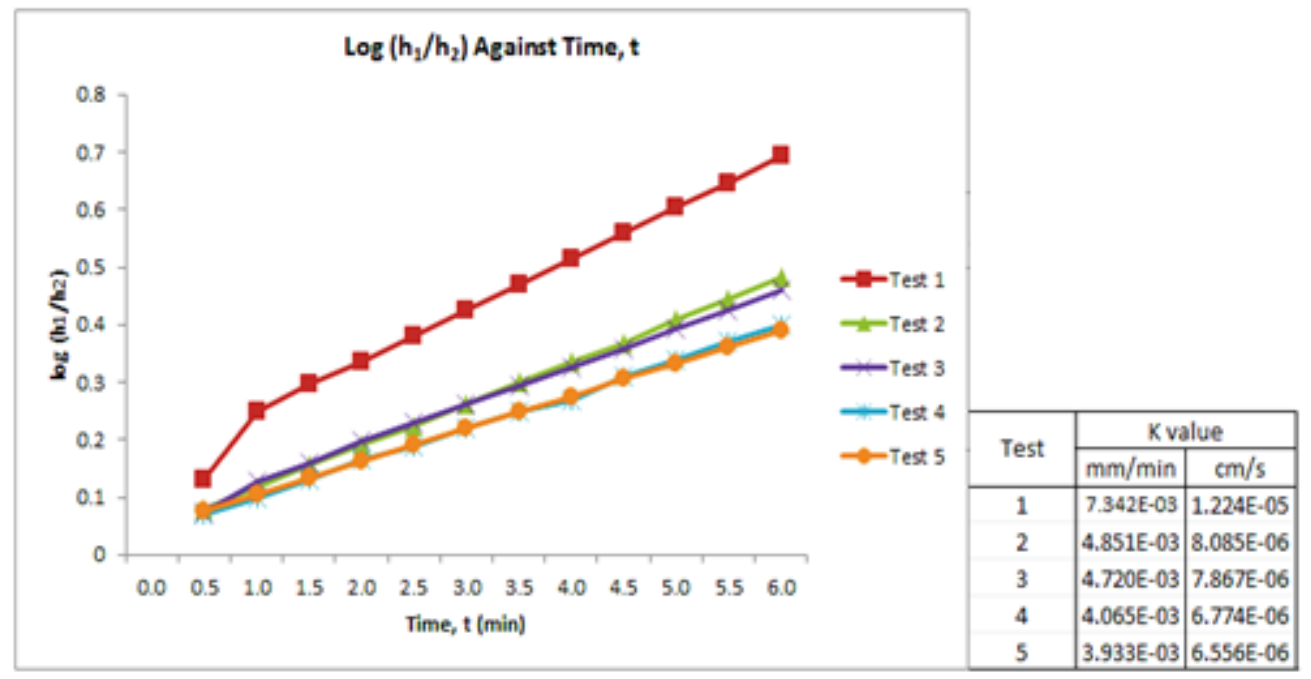

Figure 4: Graph of $\log (\mathrm{h} 1 / \mathrm{h} 2)$ against time and the unsaturated permeability for first day.

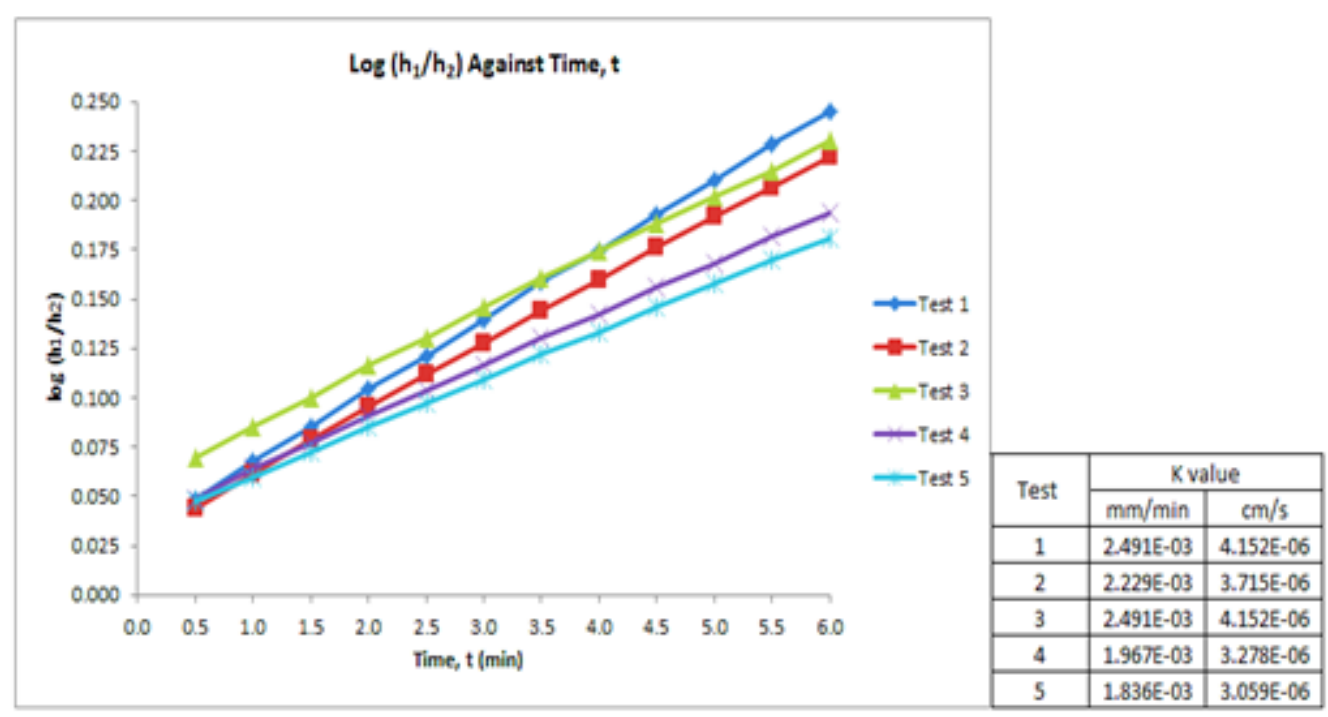

Figure 5: Graph of $\log (\mathrm{h} 1 / \mathrm{h} 2)$ against time and the unsaturated permeability for second day. 


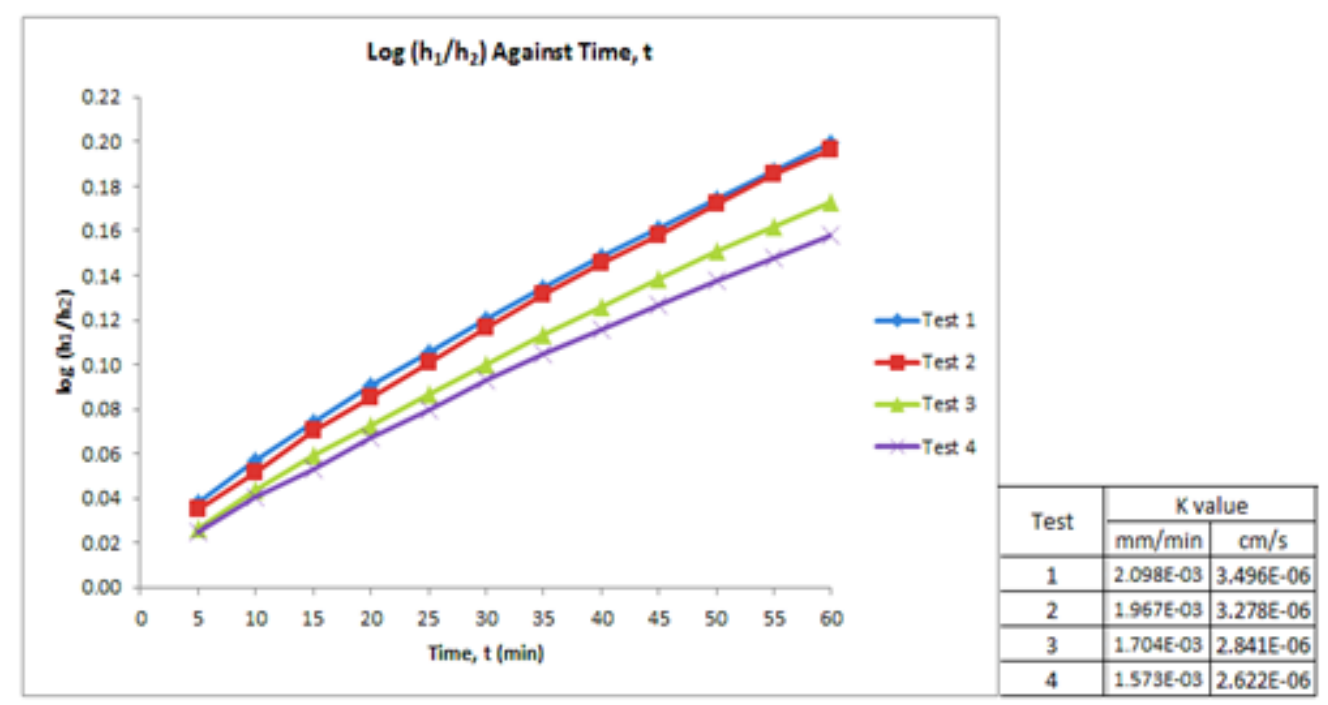

Figure 6: Graph of $\log (\mathrm{h} 1 / \mathrm{h} 2)$ against time and the unsaturated permeability for third day.

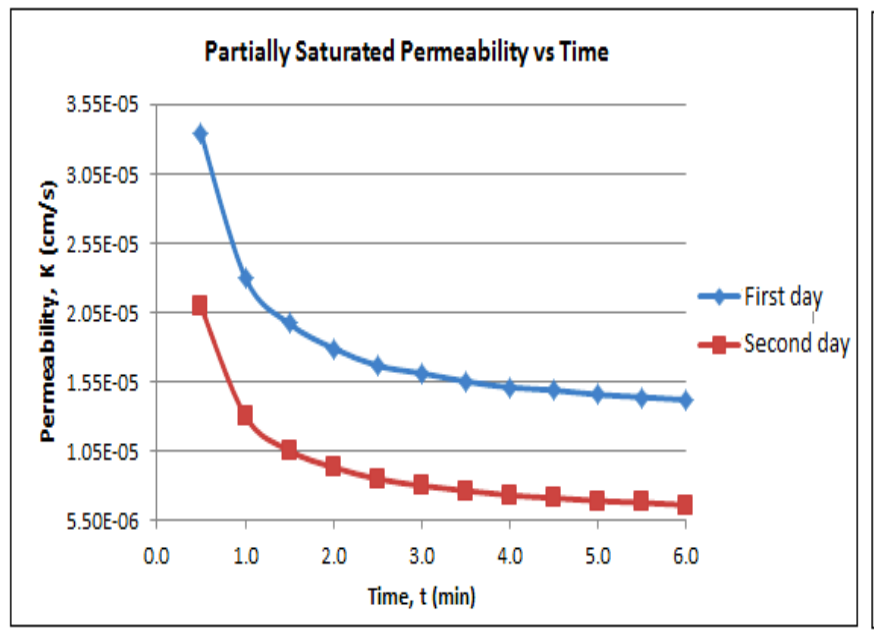

Figure 7: Partially saturated permeability.

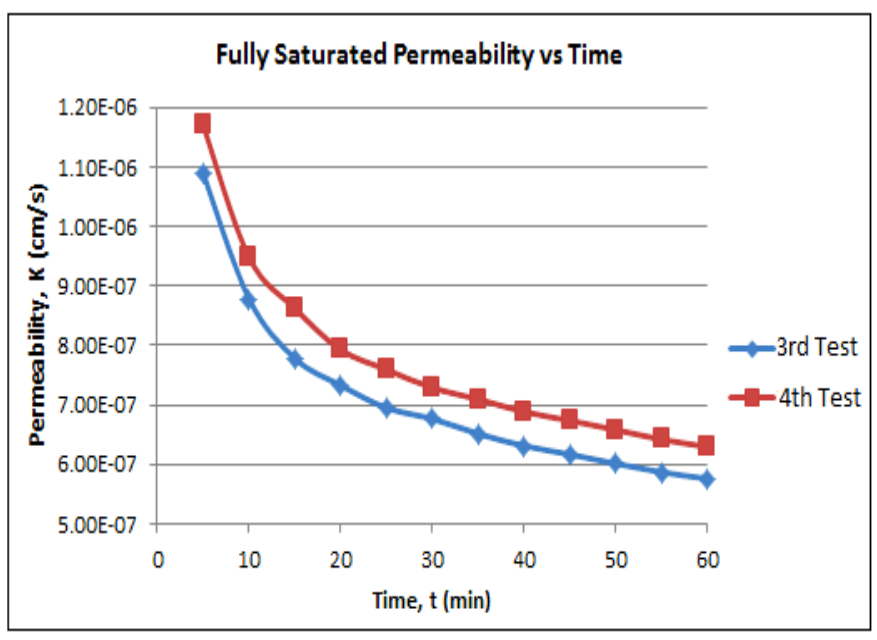

Figure 8: Fully saturated permeability.

\section{Rate of Moisture Loss for Peat Soil}

An undisturbed sample from Matang area is placed in the mould and then the whole sample is immersed in the water to simulate the peat soil condition under ground water table. The sample is allowed to saturate in the water. After sufficient time allowed for saturation, the testing for the rate of moisture loss is conducted. The moisture loss for the first 30 minutes is considered as the natural flow of water through the soil sample (free water or water from large pores) which is similar to the real condition of sampling. Thus, the graph of moisture loss is plotted for this duration of time (Figure 9). The test is repeated for another two times and the average rate of moisture loss obtained is $0.293 \mathrm{~g} / \mathrm{s}$. In terms of moisture content, i.e. moisture loss loss over the mass of dry soil of the sample, the moisture loss is about $0.06 \%$ per second. Moisture content loss within one minute is $3.53 \%$.

The moisture loss for the following 2.5 hour is considered as the loss due to draining of micro pores governed by permeability. The permeability calculated at this stage is $2.982 \times 10^{-4} \mathrm{~cm} / \mathrm{s}$ and it is considered as the partially saturated permeability of the peat soil. Since most of the water had been flow out during the first half an hour, the soil sample is thus becomes unsaturated at the moment. The average loss of moisture at this stage is $0.052 \mathrm{~g} / \mathrm{s}$ which is considerably small. 


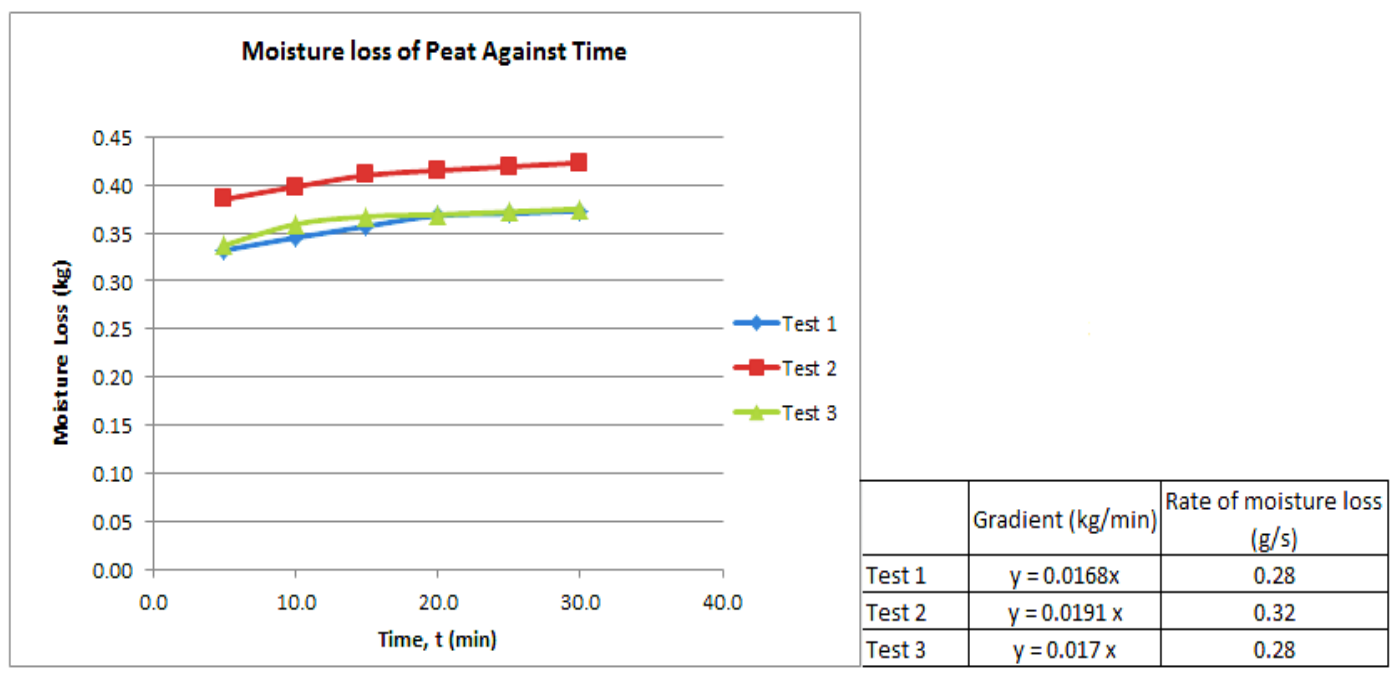

Figure 9: Graph of moisture loss against time for the first 30 minutes.

However, this test only involves sample in the mould, the data does not represent the actual condition of sampling by using peat auger since both sampler size were not same. The results only demonstrate the possibility of significant loss of moisture during the sampling process.

\section{CONCLUSION}

This study was conducted to identify the factors influencing the determination of moisture content of fibrous peat. A series of laboratory testing had been carried out during the study and the following conclusions are made based on result and analysis that had been carried out.

i. The moisture content for Kota Samarahan fibrous peat is ranged from $853 \%$ to $1138 \%$ meanwhile for Matang sample it is ranged from $201 \%$ to $1168 \%$. Hence, the sample from Kota Samarahan had higher average moisture content as compared to that of Matang.

ii. There are several factors that had been identified to affect the determination of moisture content for fibrous peat:

- The existing ground water table at location of sampling will influence the moisture content of the fibrous peat soil.

- The measurement of moisture content becomes inaccurate due to the possibility of significant amount of moisture loss when using boring method of sampling.

- Some parts of the existing standard procedures for determination of moisture content which developed based on mineral soil requirement may not be suitable for fibrous peat soil due to its high moisture and organic content.

- The physical properties of the fibrous peat soil such as particle density and organic matter content also influenced the determination of moisture content.

iii. The method of re-saturate the soil sample after sampling is necessary to regain the moisture loss. Besides, extend the drying time of the peat soil and using two stages drying will be able to make sure the moisture is totally squeezed out from the soil sample.

\section{ACKNOWLEDGMENTS}

The authors would like to express deep gratitude for the technical supports offered by the Geotechnical laboratory staff, Universiti Malaysia Sarawak (UNIMAS), Sarawak, Malaysia.

\section{REFERENCES}

[1] Martin N. Sara (1994). Standard Handbook for Solid and Hazardous Waste Facility Assessments. Lewis Publishers, an imprint of CRC Press, Inc., Florida.

[2] Mutalib A.A; Lim, J S; Wong, M H And Koonvai, L (1991). "Characterization, distribution and utilization of peat in Malaysia." Proc. of the International Symposium on Tropical Peatland (B Y Aminuddin; S L Tan; B Aziz; J Samy; Z Salmah; H Siti Petimah Choo eds.). MARDI, Kuala Lumpur. p. 7-16

[3] Jamaludin Bin Jaya (2002). Sarawak: Peat Agricultural Use, MARDI, Malaysia.

[4] Myslinska E. (2003). "Classification of organic soils for engineering geology.” Geol. Quart., 47 (1): 39-42. Warszawa 
UNIMAS E-Journal of Civil Engineering, Vol. 2 (2) 2011

[5] Faisal Haji Ali, Wong, Leong Sing and Roslan Hashim (2009). "Engineering Properties of Improved Fibrous Peat." Scientific Research and Essay Vol. 5 (2). Pp. $154-169$

[6] F.G. Bell (1993). Engineering Geology. Butterworth-Heinemann, Burlington, USA. p. 247 \& 248

[7] J. P. Andriesse (1988), Nature and Management of Tropical Peat Soils, FAO SOILS BULLETIN 59. http://www.fao.org/docrep/x5872e/x5872e08.htm, 12th August 2010

[8] Harwant Singh, Hufdi M. Bahia and Bujang B.K. Huat (2003). "Varying Perspective on Peat, It's Occurrence in Sarawak and Some Geotechnical Properties." Conference on Recent Advances in Soft Soil Engineering and Technology, 2 -4 July, 2003. Sibu, Sarawak, MALAYSIA

[9] Håkan Rydin, J. K. Jeglum, Aljosja Hooijer (2006). The Biology of Peatlands. Oxford University Press Inc, New York. p.79 \& 80.

[10] Nurly Gofar (2006). "Determination of Coefficient of Rate of Horizontal Consolidation of Peat Soil." http://eprints.utm.my/2772/1/75210.pdf, 3rd April 2011.

[11] E. Paavilainen, Juhani Paivanen (1995). Peatland Forestry: Ecology and Principles. Springer-Verlag Berlin Heidelberg, Germany. p.46 \& 47. 